\title{
FEEDING SOURCES AND TRYPANOSOME INFECTION INDEX OF Rhodnius pallescens IN A CHAGAS DISEASE ENDEMIC AREA OF AMADOR COUNTY, PANAMA
}

\author{
Vanessa PINEDA, Edilma MONTALVo, Dayra ALVAREZ, Ana María SANTAMARÍA, Jose Eduardo CALZADA \& Azael SALDAÑA
}

\begin{abstract}
SUMMARY
The sylvatic triatomine Rhodnius pallescens is considered to be the most important and widespread vector of Trypanosoma cruzi and Trypanosoma rangeli in Panama. However, its behavior and biological characteristics have only been partially investigated. Thus, to achieve sustainable and efficient control over Chagas disease in Panama, a better understanding of the ecology and biology of $R$. pallescens is essential. In this study we evaluated $R$. pallescens host feeding sources using a dot-blot assay, and the trypanosome infection index by PCR analysis in a Chagas disease endemic area of central Panama. It was found that in peridomestic palm trees, $20.3 \%$ of the examined bugs had fed on opossums (Didelphis marsupialis). However, we observed an increased anthropophagy (25.4\%) for those bugs collected inside houses. Considering the domestic and peridomestic habitats as a whole, the proportion of collected $R$. pallescens infected with trypanosomes was $87.4 \%$. In the two habitats the predominant infection was with T. cruzi (80-90\%). Between $47-51 \%$ of the analyzed triatomines were infected with T. rangeli. Mixed infections (40-51\%) were also detected. These findings provide a better basis for the implementation of a rational control and surveillance program for Chagas disease in regions where $R$. pallescens is endemic.
\end{abstract}

KEYWORDS: Rhodnius pallescens; Feeding sources; Trypanosome infection; Panama; Chagas disease.

\section{INTRODUCTION}

Sylvatic populations of the triatomine bug Rhodnius pallescens have been reported in Colombia, Panama, Costa Rica and Nicaragua ${ }^{9,13,16}$. In spite of its predominantly sylvatic behavior, the capacity of this bug to invade houses and to transmit trypanosomes to humans has been documented in several reports ${ }^{3,9,13,16}$. This triatomine is considered to be the most important and widespread vector of Trypanosoma cruzi and Trypanosoma rangeli in Panama ${ }^{9,13}$. However, its biological characteristics have been only partially investigated. It is well known that there is a strong association between this triatomine species and royal palm trees (Attalea butyracea), where the insect finds appropriate conditions, such as humidity, temperature and food availability ${ }^{10,11,15}$. This sylvatic behavior complicates the traditional Chagas disease vector control measures using insecticides. Thus, to achieve a sustainable and efficient control over Chagas disease in Panama, a better understanding of $R$. pallescens eco-biological aspects involved in the transmission of T. cruzi and T. rangeli within the different endemic regions of the country is necessary. To accomplish these aims, we evaluated host feeding sources (by a dot-blot assay) and the trypanosome infection index (by a PCR analysis) of $R$. pallescens in a Chagas disease endemic area located in Amador County, Province of Panama. The feeding patterns found confirms that $R$. pallescens cohabits frequently with Didelphis marsupialis. Our results also demonstrated that, in spite of its sylvatic habitat, this vector has a very high trypanosome transmission potential especially when it invades domiciles searching for food or attracted by the light.

\section{MATERIAL AND METHODS}

Studied area: Amador County in the province of Panama is a typical region of low land tropical forest located at an altitude ranging from 60 to 156 meters. The mean annual temperature is $26^{\circ} \mathrm{C}$ and the mean annual rainfall is $2,500 \mathrm{~mm}$. The primary original forests have been extensively destroyed for sylviculture projects and domestic animal production. The new human settlements and the deforestation of this area have favored the proliferation of royal palm trees, considered the natural habitat of $R$. pallescens. The analyzed bugs were collected in three neighboring communities: Las Pavas ( $\left.9^{\circ} 6^{\prime} 15 \mathrm{~N}, 79^{\circ} 53^{\prime} 9 \mathrm{~W}\right)$, Los Hules $\left(9^{\circ} 1^{\prime} 53 \mathrm{~N}, 79^{\circ} 55^{\prime} 35 \mathrm{~W}\right)$ and Lagartera Grande $\left(9^{\circ} 6^{\prime} 25 \mathrm{~N}\right.$, $\left.79^{\circ} 54^{\prime} 19 \mathrm{~W}\right)$. In these villages, royal palms trees are abundant and frequently found near human dwellings, most of which are constructed with natural materials, such as palm leaves and cane shafts. This area is a well-recognized Chagas endemic region in Panama ${ }^{3}$.

Triatomine collection: Approximately every two months throughout a year triatomines were collected. Bugs at peridomestic habitats were those found on palm trees near the surveyed houses (less 


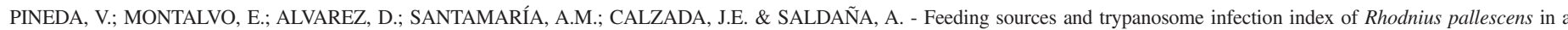
Chagas disease endemic area of Amador County, Panama. Rev. Inst. Med. trop. S. Paulo, 50(2): 113-116, 2008.

than $100 \mathrm{~m}$ ). Triatomines in these habitats were collected systematically (four people, two hours per palm) by direct searches in palm crowns partially defoliated. In addition, several palms were searched with the help of live bait traps ${ }^{8}$. At least two traps were placed on each palm crown during the afternoon and inspected the next morning.

In the domestic habitat, the collection was performed with the help of local inhabitants. Plastic containers with filter paper inside and with a $R$. pallescens picture adhered to its surface were distributed among trained inhabitants for the collection of bugs inside the houses. Once a week the containers were collected and transported to the laboratory facilities for proper triatomine identification.

Trypanosome infection and host feeding source analysis: These procedures were performed essentially as described previously ${ }^{3}$. Briefly, each collected triatomine was completed macerated using sterile scissors in $0.01 \mathrm{M}, \mathrm{pH} 7.2$ phosphate buffered saline (PBS). After centrifuging $(15,000 \mathrm{x}$ g for $10 \mathrm{~min})$, the pellet was resuspended in PBS and centrifuged once more (400 $\mathrm{x} g$ for five $\mathrm{min}$ ). The supernatant was collected and finally centrifuged at $15,000 \mathrm{x} \mathrm{g}$ for $20 \mathrm{~min}$. DNA was extracted from the parasite-containing pellet and used for the specific detection of $T$. cruzi and $T$. rangeli by a multiplex PCR analysis ${ }^{4}$. The supernatant containing soluble proteins was used for blood meal identification by a dot-blot assay using antisera against IgG from chickens, mice, dogs, opossums or humans. To improve the specificity of the assay, monoclonal antibodies against $\operatorname{IgG}$ from dogs and humans were used to confirm some positive samples.

\section{RESULTS}

A total of 27 royal palms and 67 houses were searched for the presence of $R$. pallescens in the three communities investigated. It was found that $92.6 \%$ of the evaluated palm trees were infested. In the two habitats 582 bugs were captured: 194 adult (105 males/89 females) and 388 nymphs. Sixty-four adults and three nymphs of $R$. pallescens were found in $29.8 \%$ of the investigated houses (Table 1).

A total of 337 triatomines (194 adults, 96 nymphs IV and 47 nymphs V) were analyzed to determine their blood feeding sources. A considerable amount of these specimens $(55.5 \%$; 187/337,) were too dry or did not contain sufficient ingested blood for host identification. Additionally, in many bugs $(44.5 \%$; 150/337) with apparently sufficient blood it was not possible to identify the feeding profile. It is likely that other vertebrates not evaluated in this study were the blood sources of these triatomines. The percentage of bugs positive for a determined type of blood $(27.3 \%$; 92/337) is depicted in Fig. 1. In the peridomestic palm trees, $20.3 \%$ of the examined bugs had fed on opossums. Interestingly, we observed an increased anthropophagy (25.4\%) in adult bugs collected inside houses. Two of the three nymphs collected inside houses were also positive for human blood. In peridomestic and domestic habitats, the finding of positive triatomines for the other evaluated feeding sources (birds, dogs and mice) was in all cases less than $3.0 \%$.

No significant difference was observed in the triatomine trypanosome infection index between the domestic and peridomestic habitat. Considering the two investigated habitats as a whole, the proportion of $R$. pallescens infected with trypanosomes was $87.4 \%$ among the 119 adults individually examined. The $T$. cruzi, T. rangeli and mixed infection index detected in each habitat is depicted in Fig. 2. The predominant infection was with T. cruzi (80-90\%). Between

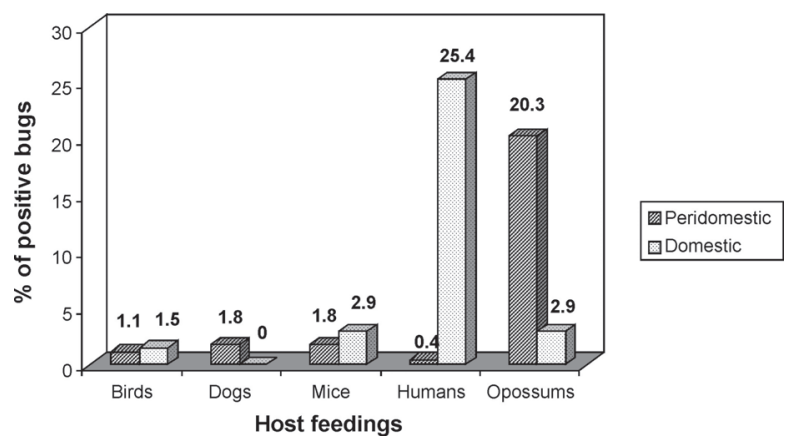

Fig. 1 - Feeding sources of Rhodnius pallescens collected in peridomestic palm trees and domestic habitat of the Amador County, Panama. The blood meal of individual bugs was investigated using a dot-blot assay designed to detect IgG from birds, dogs, mice, opossums or humans.

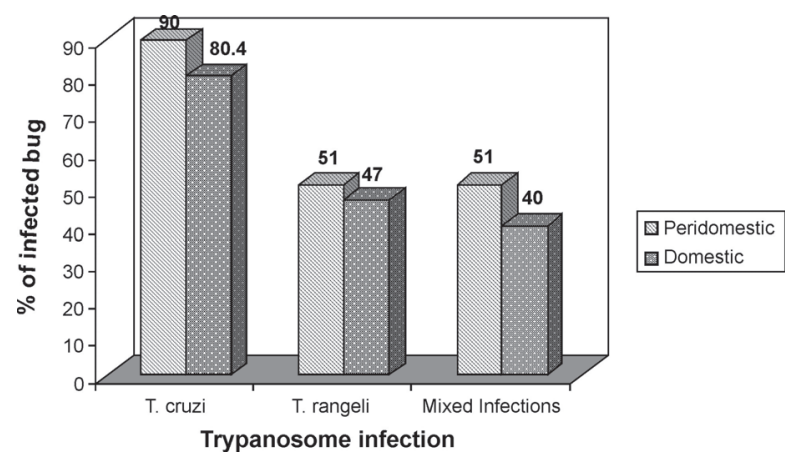

Fig. 2 - Trypanosome infection of Rhodnius pallescens collected in peridomestic palm trees and domestic habitat of the Amador County, Panama. Each individual triatomine was analyzed for the presence of Trypanosoma cruzi and/or Trypanosoma rangeli infection using a multiplex PCR assay.

Table 1

Rhodnius pallescens collected in domestic habitat and peridomestic palm trees from Amador County, Panama

\begin{tabular}{lcccccc}
\hline Habitat & Adults & N1* & N2 & N3 & N4 & N5 \\
\hline Domestic & 64 & 0 & 0 & 0 & 3 & 0 \\
Peridomestic palm trees & 130 & 18 & 104 & 123 & 93 & 67 \\
\hline Total & 194 & 18 & 104 & 123 & 96 & 47 \\
\hline
\end{tabular}

$* \mathrm{~N}=$ Nymph stage 


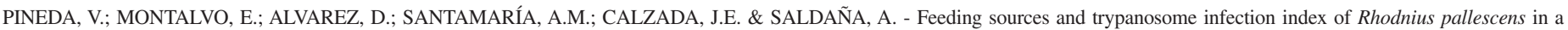
Chagas disease endemic area of Amador County, Panama. Rev. Inst. Med. trop. S. Paulo, 50(2): 113-116, 2008.

$47-51 \%$ of the analyzed bugs were infected with $T$. rangeli and mixed infections were also frequently detected $(40-51 \%)$.

\section{DISCUSSION}

In the Isthmus of Panama, the presence of $R$. pallescens has been known since $1932^{2}$. This triatomine is considered as the main vector of Chagas disease in central Panama ${ }^{9,13}$ and a frequent inhabitant of the palm tree A. butyracea $a^{10,11,15}$. Recent investigations have described important biological characteristics of $R$. pallescens and its relationship with the occurrence of Chagas disease ${ }^{3,6,14,16}$. Based on these findings, it has been suggested that a successful control of Chagas disease transmission by this particular sylvatic vector depends on a constant entomological surveillance in each particular endemic region.

During one year of investigation, 27 royal palms and 67 houses were searched for the presence of $R$. pallescens in the three villages explored. The transmission of $T$. cruzi and T. rangeli to humans in this region is associated with infected adult bugs, which fly from palm trees to nearby houses ${ }^{10}$. Thus, the proximity of $A$. butyracea trees to houses is considered a Chagas disease risk factor. The fact that $92.6 \%$ of the evaluated palms in this study were infested supports this idea. An aggravated situation is that those palms near houses apparently present high $R$. pallescens densities (data not shown). This observation could be related with better food availability for triatomines, since the presence of wild and/or synanthropic animals such as D. marsupialis are common on these peridomestic palms.

As expected, mainly adult bugs of both sexes were found in the domestic habitat. However, some nymphs were also collected in this environment. The finding of immature stages inside three houses may indicate an adaptation process of this triatomine to specific conditions found in human dwellings of the study area. A similar observation was reported by PIPKIN in $1968^{\circ}$. This finding confirms the viability of this triatomine to expand its natural ecotope as demonstrated for other species of Rhodnius ${ }^{1,7,12}$.

An important feature for the presence of $R$. pallescens inside human dwellings is the proximity to palm trees. Unexpectedly, some adult specimens were found inside houses that were not less than three hundred meters from the nearest palm trees. Although $R$. pallescens is not considered a good flyer, some inhabitants report that they frequently kill flying bugs that entered the domicile attracted by lights. These observations call attention to the flying capacity of this triatomine. On the other hand, we think that the passive transportation of bugs from palm trees to houses with palm leaves used for structuring the roofs is a rare event. Usually local farmers cut down green palm leaves during the daytime without perturbing the rest of the palm crown. Our field observations indicate that at this time of the day most of the bugs are hidden very inside of the palm crown where the humidity is elevated and the light is sporadic. Moreover, we have performed active searches for $R$. pallescens eggs attached to palm leaves without any success.

In relation with the bug feeding sources, it was found that in peridomestic palm trees $20.3 \%$ of the examined bugs had fed on opossums but for those bugs collected in houses the predominant meal was the human blood $(25.4 \%)$. The findings of positive bugs for the other feeding sources (birds, dogs and mice) were in all cases less than
$3.0 \%$ in peridomestic and domestic habitats. These results confirm that the opossum blood meal is common between bugs collected on palms located at less than $100 \mathrm{~m}$ from the surveyed houses. A comparable finding was described in Panama by CHRISTENSEN \& VASQUEZ ${ }^{5}$. However, our results differ particularly with that study, in which it was reported that many triatomines (including nymphs) collected in peridomestic palm trees had fed on humans. This particular event is uncommon $(<1 \%$ in our observations) and we think that most triatomines that fly inside houses and feed on humans never return to the palm trees. It is likely that the precipitin assay used by these investigators was not sufficiently specific. In this sense, the presence of monkey blood meal was also tested in the present study, however a high cross-reactivity with human blood was found (Data not shown).

Considering the two habitats as a whole, it was found that the proportion of $R$. pallescens infected with trypanosomes was $87.4 \%$ among the 119 adults individually examined. Based on the finding that many bugs had fed on opossums, this high infection trypanosome index could be the result of a natural coexistence with this T. cruzi and T. rangeli reservoir.

The predominant trypanosome infecting $R$. pallescens was T. cruzi $(80-90 \%)$. Between (47-51\%) of the analyzed bugs were infected with T. rangeli. Additionally, mixed infections (40-51\%) were also found. A high proportion $(80.0 \%)$ of the triatomines collected inside houses was infected with T. cruzi and $68 \%$ of these bugs had fed on humans. These findings could give some explanation on how T. cruzi and $T$. rangeli are frequently transmitted to humans in these areas without apparent vector domiciliation.

This study improves our understanding of $R$. pallescens ecobiological characteristics in rural areas of central Panama. Also it provides better basis for the establishment of national vector control programs particularly designed for surveillance and monitoring not only in the domestic environment but also in palm trees of nearby communities.

\section{RESUMO}

\section{Fontes de alimentação de $R$. pallescens e índice de infecção por Trypanosoma em área endêmica da doença de Chagas em Amador, região central do Panamá}

O triatomíneo silvestre Rhodnius pallescens é considerado o mais importante vetor do Trypanosoma cruzi e Trypanosoma rangeli no Panamá. Entretanto, seu comportamento e características biológicas são pouco estudados. Para controlar a doença de Chagas no Panamá é necessário melhorar a compreensão dos aspectos eco-biológicos do $R$. pallescens. Neste estudo, investigaram-se as fontes de alimentação de $R$. pallescens usando dot-blot e o índice de infecção por Trypanosoma por metodologia molecular, em área endêmica da doença de Chagas na região central do Panamá.

Foi observado que $20,3 \%$ dos barbeiros coletados em palmeiras peridomésticas se alimentavam de gambás (Didelphis marsupialis). Contudo, barbeiros coletados dentro das residências apresentaram antropofagia aumentada $(25,4 \%)$. Considerando o ambiente doméstico e peridoméstico juntos, o percentual de $R$. pallescens infectados com Trypanosoma foi de 87,4\%. Nos ambientes doméstico e peridoméstico, 


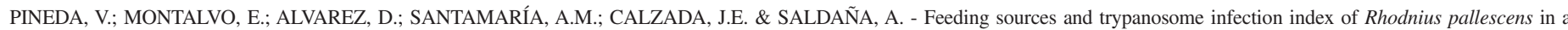
Chagas disease endemic area of Amador County, Panama. Rev. Inst. Med. trop. S. Paulo, 50(2): 113-116, 2008.

a infecção por T. cruzi foi de $80,4 \%$ e $90 \%$; a infecção por $T$. rangeli foi de $47 \%$ e $51 \%$, respectivamente. Observou-se infecção mista em $43 \%$ dos triatomíneos coletados em ambiente doméstico e em $51 \%$ dos triatomíneos peridomésticos. Estes achados fornecem embasamento para a implementação de um controle adequado e um programa de vigilância para a doença de Chagas em regiões onde o $R$. pallescens é endêmico.

\section{ACKNOWLEDGEMENTS}

The authors thank Franklin Samudio for helping with PCR analysis and Roberto Rojas and Jose Montenegro for excellent fieldwork. We are also grateful to Marcia Laurenti, Edenice Fonseca and Derliane Oliveira for helpful comments and the summary in Portuguese.

The present investigation received financial support from the UNDP/World Bank/WHO Special Programme for Research and Training in Tropical Diseases (TDR). Grant A304558 and from Grant PAN 6010, International Atomic Energy Agency (IAEA).

\section{REFERENCES}

1. ABAD-FRANCH, F.; PALOMEQUE, F.S.; AGUILAR, V.H.M. \& MILES, M.A. - Field ecology of sylvatic Rhodnius populations (Heteroptera, Triatominae): risk factors for palm tree infestation in western Ecuador. Trop. Med. Int. Hlth, 10: 1258-1266, 2005 .

2. BARBER, H.G. - A new species of Rhodnius from Panama (Hemiptera: Reduviidae). Wash. Acad. Sci., 22: 514-517, 1932.

3. CALZADA, J.E.; PINEDA, V.; MONTALVO, E. et al. - Human trypanosome infection and the presence of intradomicile Rhodnius pallescens in the western border of the Panama Canal, Panama. Amer. J. trop. Med. Hyg., 74: 762-765, 2006.

4. CHIURILLO, M.A.; CRISANTE, G.; ROJAS, A. et al. - Detection of Trypanosoma cruzi and Trypanosoma rangeli infection by duplex PCR assay based on telomeric sequences. Clin. diagn. Lab. Immunol., 10: 775-779, 2003.

5. CHRISTENSEN, H.A. \& DE VASQUEZ, A.M. - Host feeding profiles of Rhodnius pallescens (Hemiptera: Reduviidae) in rural villages of Central Panama. Amer. J. trop. Med. Hyg., 30: 278-283, 1981.
6. JARAMILLO, N.; SCHOFIELD, C.J.; GORLA, D. et al. - The role of Rhodnius pallescens as a vector of Chagas disease in Colombia and Panama. Res. Rev. Parasitol., 60: $75-82,2000$

7. MATIAS, A.; DE LA RIVA, J.; MARTINEZ, E.; TORREZ, M. \& DUJARDIN, J.P. Domiciliation process of Rhodnius stali (Hemiptera: Reduviidae) in Alto Beni, La Paz, Bolivia. Trop. Med. Int. Hlth, 8: 264-268, 2003.

8. NOIREAU, F.; ABAD-FRANCH, F.; VALENTE, S.A. et al. - Trapping Triatominae in silvatic habitats. Mem. Inst. Oswaldo Cruz, 97: 61-63, 2002.

9. PIPKIN, A.C. Sr. - Domiciliary reduviid bugs and the epidemiology of Chagas' disease in Panama (Hemiptera: Reduviidae: Triatominae). J. med. Entomol., 5: 107-124, 1968.

10. ROMAÑA, C.A.; BRUNSTEIN, D.; COLlin-DElAVAUD, A.; SOUSA, O. \& ORTEGA-BARRIA, E. - Public policies of development in Latin America and Chagas' disease. Lancet, 362(9383): 579, 2003.

11. ROMAÑA, C.A.; PIZARRO, J.C.; RODAS, E. \& GUILBERT, E. - Palm trees as ecological indicators of risk areas for Chagas disease. Trans. roy. Soc. trop. Med. Hyg., 93: 594-595, 1999.

12. SANCHEZ-MARTIN, M.J.; FELICIANGELI, M.D.; CAMPBELL-LENDRUM, D. \& DAVIES, C.R. - Could the Chagas disease elimination programme in Venezuela be compromised by reinvasion of houses by sylvatic Rhodnius prolixus bug populations? Trop. Med. Int. HIth, 11: 1585-1593, 2006

13. SOUSA, O.E. \& JOHNSON, C.M. - Prevalence of Trypanosoma cruzi and Trypanosoma rangeli in triatomines (Hemiptera: Reduviidae) collected in the Republic of Panama. Amer. J. trop. Med. Hyg., 22: 18-23, 1973.

14. VASQUEZ, A.M.; SAMUDIO, F.E.; SALDANA, A.; PAZ, H.M. \& CALZADA, J.E. Eco-epidemiological aspects of Trypanosoma cruzi, Trypanosoma rangeli and their vector (Rhodnius pallescens) in Panama. Rev. Inst. Med. trop. S. Paulo, 46: 217 $222,2004$.

15. WHITLAW, J.T. \& CHANIOTIS, B.N. - Palm trees and Chagas' disease in Panama. Amer. J. trop. Med. Hyg., 27: 873-881, 1978.

16. ZELEDON, R.; MARIN, F.; CALVO, N.; LUGO, E. \& VALLE, S. - Distribution and ecological aspects of Rhodnius pallescens in Costa Rica and Nicaragua and their epidemiological implications. Mem. Inst. Oswaldo Cruz, 101: 75-79, 2006.

Received: 7 May 2007

Accepted: 31 January 2008 